\title{
A Modern-Day Diary: Notes for Future Humans
}

\author{
Matti Itkonen \\ University of Jyväskylä, Finland
}

\section{Abstract}

Time and being can be seen as a space. A modern-day diary is a way of exploring that space or state of being. Outlining and shaping it requires word, image and imagination. The question is framed cultural-philosophically, and the mode of writing is poetic essayism. Otherwise, the creative untangling and differentiation of the poetics of lived space is not possible. After all, the goal is to combine science and art and weave them into the same reflective fabric. The essential aspects include thoughts about the fullness and filling of something, about its fulfilment. Then the present moment is not seen as marking a boundary in just one direction: it is not just an endpoint of the past. Nor is it exclusively the starting point of the future. The present must be seen as a boundary in two directions. The researcher's gaze can simultaneously focus on both the bygone and the future. Consciousness meanders backwards down memory lane and journeys forwards on a trip of anticipation. A moment of insight means the fulfilment of time. Time is right for a deepening of selfunderstanding. Simultaneously, it also means fulfilling the ideal of selfreflection: an overall picture, clear and enlightened, of the the self's place in time and being. When humans long for the past or dream of the future, they are living in the impasse of a now-moment. It is not a boundary in any direction. It is, in fact, a dimensionless photographic moment. Its spatial selfcontainedness results in no more than semi-fulfilment. The present becomes irrelevant. In fulfilment, humans themselves are the boundary facing in all directions. The overall perception of the enlightened subject reveals a reality that includes freedom, space, and human existence. Then it is easy for each and every person to exist as their own self.

Keywords: modern-day diary, temporal topos, spatial topos, machine man, essay writing, utopia, life journey

\section{Introduction}

This is a narrative within a narrative: a partial story constructing a larger story ${ }^{1}$. Without this framework narrative, the whole would be incomplete. It would lack a plot. It would be like the empty frame of a work of art: a surround without a painting. 
Time builds the frame. Being shapes the content. The researcher is both spectator and artist. As an essayist, he plays the simultaneous roles of sender and recipient. From the parts making up the whole, he shapes a unified composition. In its implementation, the composition is a philosophical inquiry: the joint narrative of image and word.

What could the existential recipe mean to a future human? How could we describe this present moment to an inhabitant of days yet to arrive? What kind of existential memory of the 2020s is worth passing on to future times as a document? How would it be possible to make assumptions about the thinking of future humans, and what would we assume? Would their everyday life be reminiscent of the habitual daily course of modern man? Or would some things have significantly changed? What would be similar and what would be crucially different? Would the presentness of the future also mean some kind of period of upheaval? Can time automatically mark a turning point in being? What is the human's place at such existential turning points?

\section{Contemporary observations}

There is no shortage of interesting questions. My thinking needs a helping hand. An excellent work to support my reflections is von Wright's book Ihminen kulttuurin murroksessa (Man in the Transformation of Culture). In it, he examines Spengler's philosophy of history and focuses on the symbolism of space. What is important is von Wright's observation on Greek and Latin. The text sparks enthusiasm for further rumination: "It is worth noting that there is no word in Greek, nor in Latin, that exactly corresponds to the word space. The Greek topos means place, i.e. the position of an object relative to other objects. The Latin spatium, on the other hand - from which English and French have derived the word space - refers mainly to the distance or gap (between two objects)". (von Wright, 1996, p. 122.)

Here we shall do some adapting and draw a parallel between levels of time and objects. The contemporary observer thus investigates three "time objects": past, present, and future. Perhaps now we could also use the term experiential space. The distance and relationship between the time dimensions are examined through the concepts of memory, perception, and expectation or anticipation. Language and photographs will function as the vehicles of time travel. Likewise, the idea of a period of upheaval is central, which always involves a critical turning point with some aspects undergoing a decisive existential change. Things take a new direction. The spirit of the age changes, becomes different. Usually, the situation then also requires people to apply themselves and make sacrifices. There has to be a steadfast belief and trust in ideals.

A temporal topos is inevitably also a spatial topos: from some point we must make contemporary observations and interpret the present moments of different periods. The precise same physical location means something different in the past, present, and future. Then we are talking about the relation of a place to itself, to its 
quintessential qualities in both its past and future. The significance currently attributed to a place changes in relation to the bygone and the hereafter. Often the change and the period of upheaval occur together. In other words, a turning point brings about an alteration in the reality of values - at least momentarily. Of course, some of the changes may be permanent. Contemporary observation needs to be refined.

Nationality and internationality, what was their significance before? And what is the significance of familiarity and strangeness now and in the future? The distance between these states is thus both local (spatial) and temporal. It is also closely linked to national sentiment as well as to one's view of world citizenship. Mere reflection is no longer enough. I need some additional material to support my thinking and interpretations: my deliberations call for literature and photographs.

Professor Mazzarella's extensive production includes numerous interesting works. Her text also lends itself to the analysis of contemporary observations. The book Alma is skilfully constructed. It describes phases in the life of Alma Söderhjelm, Finland's first female professor. The Latin word "spatium" mentioned by von Wright occurs as she remembers Paris and the time spent there working on her dissertation. The temporal distance between what was then the present and the past is poignantly described. The past and Paris display themselves as existential highpoints:

"As soon as I close my eyes, I can relive my walks in Paris. The lines of the beautiful buildings, the Seine with its boats, the twilight above the bridges, splendidly outlined against the heavy winter sky or gracefully in the spaciousness of spring days, the riverfront streets with their boxes of books where I often spent hours browsing and reading, the winding streets, the never-ending boulevards - I liked this more than anything else I've ever liked, with the exception of human beings." (Mazzarella, 2018, p. 119.)

So it is possible for us to get attached even to a place. Or is it that we are attracted to a certain era and a place associated with it? Still, the fascinating attachment to a place is obviously different from the way we become attached to another person. A couple of pictures will help to refine our contemporary observation. 


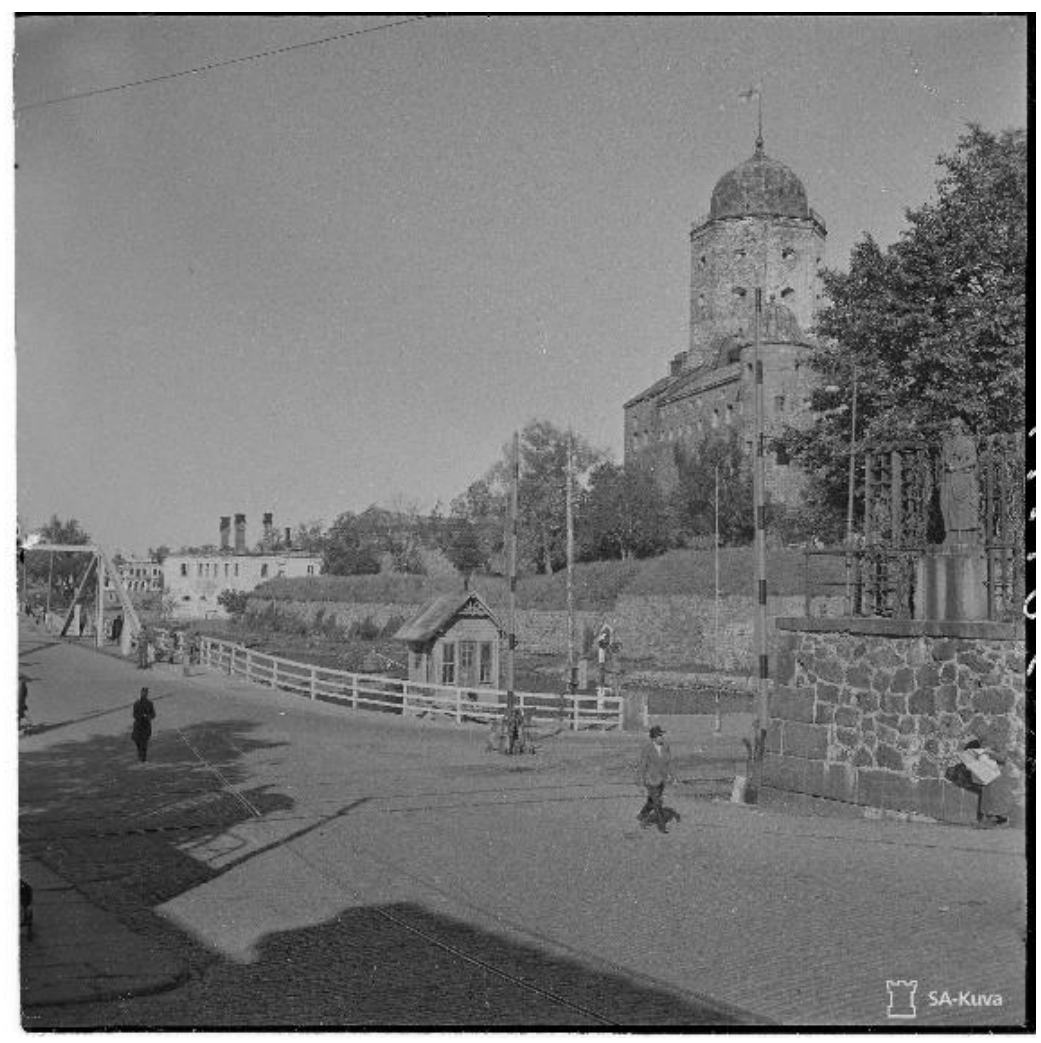

Photograph 1. Vyborg Castle.

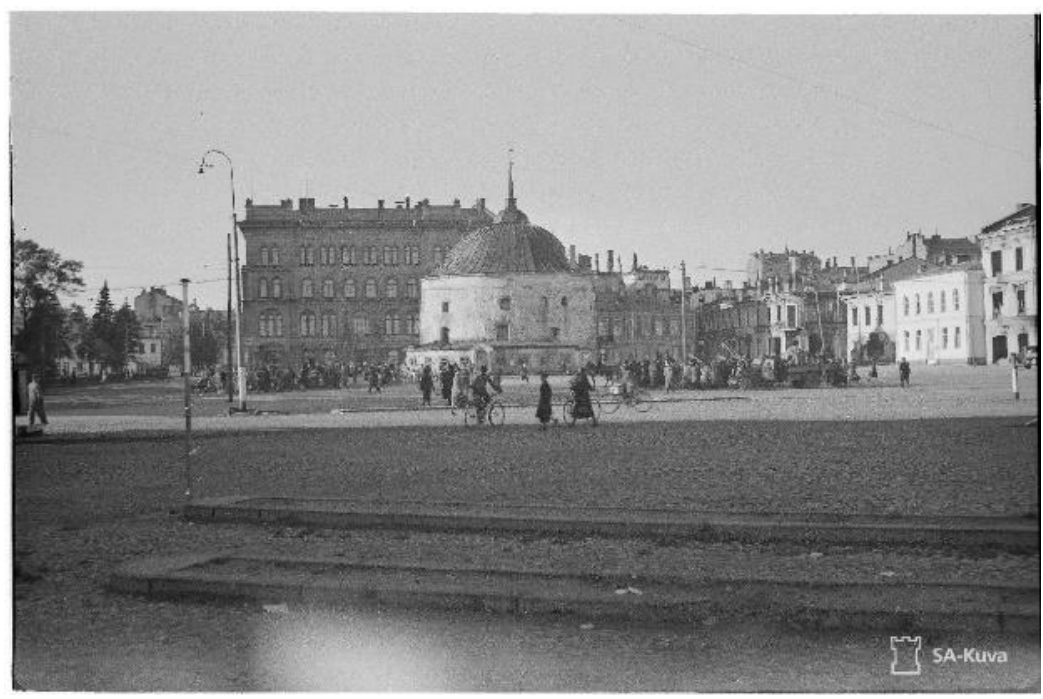

Photograph 2. Life in Vyborg Market Square. 
The 1940-1941 interim peace and especially the 1944 final peace marked disastrous turning points in Finnish history. There was no going back. The concrete direction of people's existence was forward. Their inner direction, however, was the direction of longing: people's thoughts gravitated back to their lost home and to Karelia. At the same time, two spatium elements also appear in reality: temporal and locational distance. Vyborg begins to resemble the Paris in Mazzarella's work. The most important difference, however, is the difference between coercion and choice. Vyborg remained beyond the border, and it was out of bounds. Alma Söderhjelm, on the other hand, was able to go back to Paris if she wanted. Measured in kilometres, Vyborg was not far from the new border. In time measured by a clock, the distance was still quite short in the 1950s. However, the distances between internal time and the time of longing were quite different. And it is there that the content of eternity is defined in a new way. Even a short temporal difference can feel like an eternity.

For many, photographs one and two probably told of a dreamtime, an era of happiness, and I don't mean the ongoing Continuation War. It is a time of affection and of being at home. So it amounts to the same thing as Söderhjelm's liking of Paris. Yet it is a liking that differs from affection for another person. A return to the blissful past is possible by closing your eyes. Then an eternity transforms into a presence. Temporal and locational distance disappear. Perhaps the moment could be called an expanded instant of imagination or memory. Actually, at this point, the most important thing is atmosphere, which is why we are justified in looking simultaneously at Vyborg Castle and its market life.

What would a person of that time have told a future person about Vyborg? What kind of chronicle would they have sent to posterity in an imaginary future? Perhaps they would have started their description with a short quote from the moving book Karjala, muistojen maa (Karelia, Land of Memories). At the end of the book there is a short section of text which includes Lempi Jääskeläinen's eloquent piece "Beautiful, Old Vyborg". Jääskeläinen's use of words is skilful: "Dear old Vyborg - I thank you for everything. For a bright, sunny childhood, when I ran along your old ramparts with my hair flowing and fluttering in the wind and I collected yellow dandelions or their fluffy balls, blowing every seed out and away just like the other children of old Vyborg - and the blue Vyborg Bay sparkled in the dazzlingly bright sunshine..." (Jääskeläinen, 1940, page number missing.)

Modern men and women, beings of the 2020s, how would they read the emotional beginning of a letter? What would Vyborg mean to them today? Probably it would be just a transit point en route to St. Petersburg. If this is a correct assumption, the end result is both sad and without history. Beautiful writing demands the right kind of reader for whom Jääskeläinen's words would be a lived reality and a reflection of a lost time. If a person has lived during the time when Vyborg was part of Finland, they will be able to understand the national significance of the market square and the castle. Admittedly, attachment to a place can also arise from the stories recounted by 
people close to you. So, in that way, the Vyborg story may acquire transgenerational importance. Art is likewise simultaneously able to make a similar impression. The narrative power of word and image should not be underestimated.

A short excerpt from Kersti Bergroth's novel Nuoren lotan päiväkirja (The Diary of a Young Lotta Svärd) provides a link between the photographs and the extract from Lempi Jääskeläinen. Bergroth's beautiful description brings the reader to a stop: "We are all thinking of Vyborg these days. We are beginning to realize that the time to leave Vyborg may soon have come. [- - ] Vyborg, my hometown. You are almost like a living creature to me. [- - ] No one who has lived in Vyborg can imagine anything as crushingly sweet as spring on the ramparts of Vyborg. It has all the things you long and yearn for - a longing for the sea, a longing for hope, a longing for Karelia, a longing for history. When you are young and walk on the ramparts of Vyborg, you sense the heartfelt rapture of the whole world." (Bergroth, 1940, p. 95.)

How much does the knowledge that something has definitively been lost influence your attachment to your hometown? Jääskeläinen's and Bergroth's attachment to Vyborg is even stronger than Söderhjelm's attachment to Paris. An essential element, however, is probably the idea of the home or being at home. Maybe that's the very reason why photos one and two make Vyborg seem so close. The photos probably also bring back memories of wartime days. We can assume that Jääskeläinen's touching words encapsulate the feelings of an entire generation: "You bring to mind more and more bright new pictures from years ago... You have given me everything under the sun a person can ask for. A home - youth - happiness - a life mission... Then I lost everything with you. - When I left, you stayed to be destroyed and disappear into the night... Ah, dear old Vyborg..." (Jääskeläinen, 1940, page number missing.)

It is as if the power of Bergroth and Jääskeläinen's emotion multiplies and intensifies the amount of affection that Alma Söderhjelm felt for Paris. It cannot be merely a matter of language. Of course, the potency of the description or perhaps even its fervour significantly affects the reader's interpretation. Vyborg Castle has obviously also had a symbolic importance. Its loss and the hoisting on its tower of a foreign power's flag was a concrete sign of the conclusive arrival of "destruction and night". Perhaps it is only at the moment of loss that the magnitude of something is revealed. Then all the platitudes and truisms cease to exist. Nothing can replace the preciousness of a home. Only a person who has experienced loss may somehow understand the overwhelming harshness of the pain. The imagination of later generations is not enough.

One more pair of pictures is needed. An essential element is the Round Tower, still located on the Vyborg Market Square and visible in photo two. Thus, in photographs three and four, the viewer moves inside shot number two: into the Round Tower. And so a very multi-level journey through time begins. 


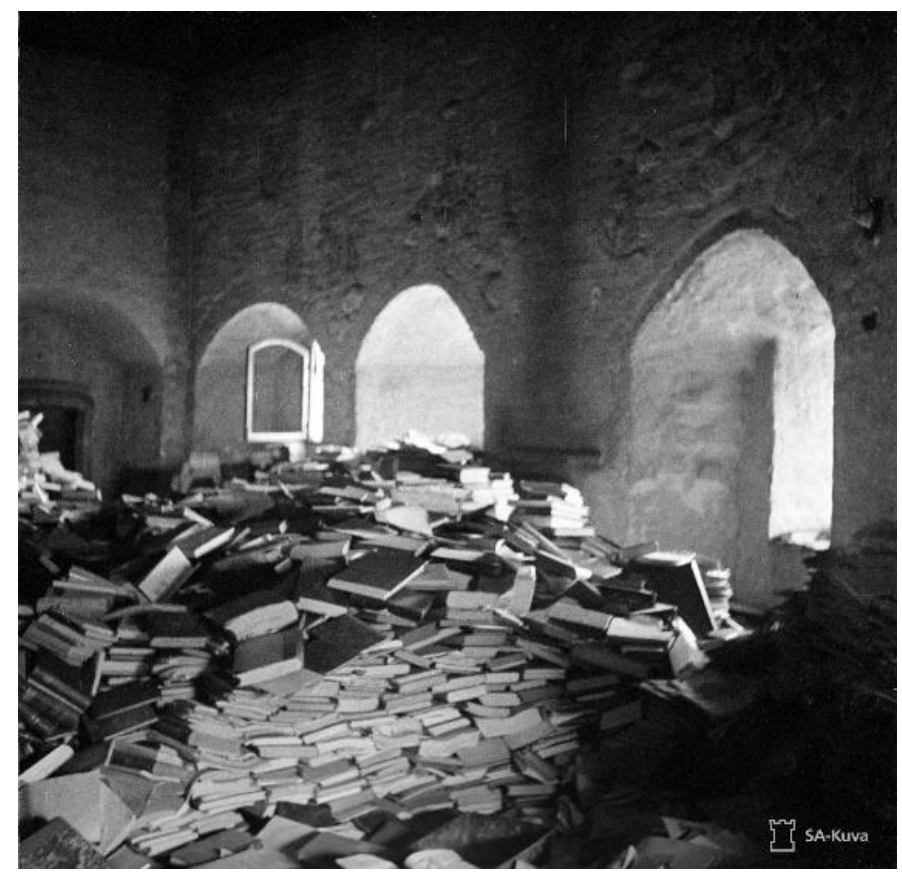

Photograph 3. The tower of books.

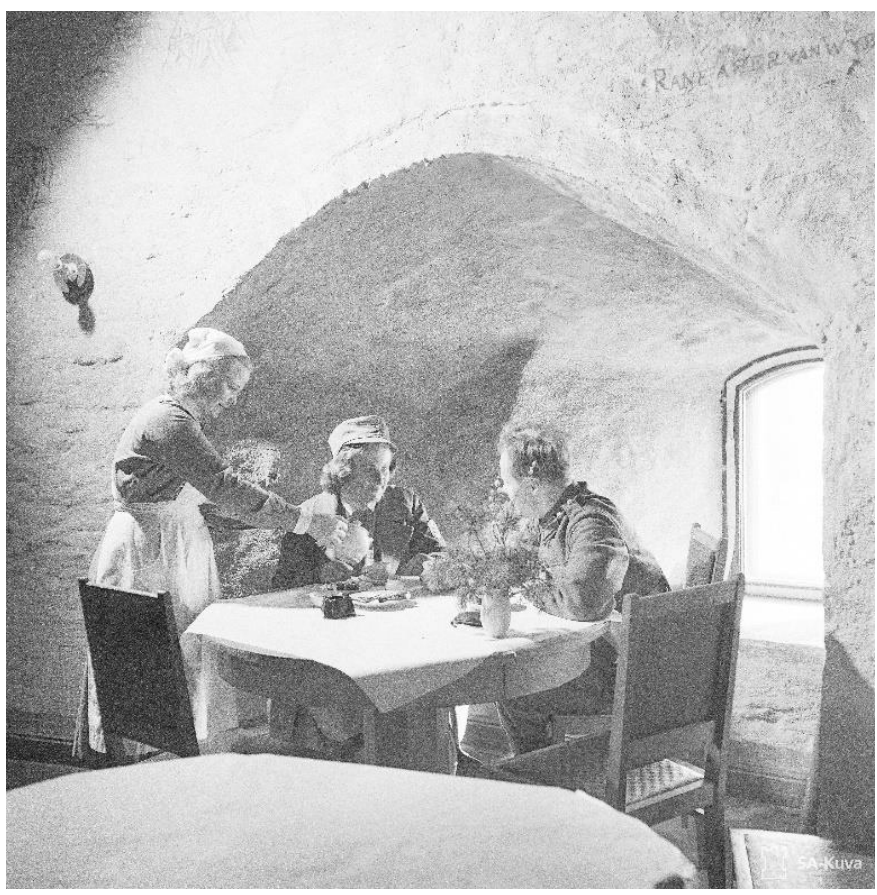

Photograph 4. The tower of hospitality. 
Understanding the past requires imagination. There has to be an ability to see the time path leading into the past, as well being able to imagine journeying along that existential path. The time landscape also opens up in a forward direction. It is in that direction that the path to the future takes you. Even then, hiking the path requires imagination. In other words, in addition to a destination, you have to somehow know the different stages of the hike.

Professor Mazzarella touches on the path of time in her interesting book Marraskuu (November): "It was impossible to imagine what it would be like to be fifty. In fact, it was impossible to imagine what it would be like to be thirty or forty. This was precisely where the problem was: she could imagine how it felt to be like a grandmother, old and wise, with a life already lived, but she couldn't visualize the path that led there." (Mazzarella, 2004, p. 169.)

There is truth in a word. Language is truth's mode of being. The book is the home where word, language, and truth reside. At historic turning points, we endeavour to protect that home of civilization. Or we consciously seek to destroy it. It may also well be that there exist truths from different eras. Can the truth ever be timeless, immutably permanent?

The existential frame of both photograph three and four is still war. The essential and precise point here is that it was the time of the Continuation War. Then things were being recaptured and not merely lost. Who has collected and placed this literary mound in the tower of books? The question is, in fact, of decisive importance. The act of piling is based on either respect or contempt. From the point of view of Finnishness, it can only be a matter of respect. For the Soviet Union, it would have probably meant mere contempt.

However, the curent investigations are not war correspondence or propaganda. Neither is it a question of war toursim. Therefore, any war-related reflections and interpretations will be left for another time. Now the focus is on other things.

In the spirit of Mazzarella's text, it would now be possible to ask, "How, for example, can I, as a person of the 2020s, imagine a path to the towers of books and hospitality?" What about a person of the future compared to me: how will an inhabitant of the 2040s find an existential path back to the past and to the days of the Continuation War? Does imagination backwards differ from imagination forwards? There is written and pictorial evidence of the past. The future, though, can be connected to intimations or harbingers. In general, the inklings we have then mean daydreams or nightmares. It is a different matter to depict the state of the world using memories rather than predictions. Which is why a letter of the past and a letter of the future differ somewhat.

A letter from the tower of books might begin, for example, as follows: "Can contempt for our national society and culture be more clearly visible? Belittling the intellectual achievements of a neighboring nation is an excellent way of showing power. At the 
same time, however, it also reveals one's own barbarity." What are all the things that a person of the future could read from those words? Or what things could they imagine finding out from the books?

By following tracks, we can return to the bygone. So how do we then move towards the days that have yet to arrive? The Round Tower was a nationally symbolic place. It was easy for the conqueror to show his supremacy by raising his own flag on the castle tower and stacking up nationally important works in the Round Tower. It is easy for a person of the future to be appalled by such information. The impression can be further heightened by the emotional nature of the description of a contemporary letter sent from the past. The reply posted to the past could also be bemoaning and lamenting in tone. How else could one really think of comforting people who have lost their homes?

A knowledge of history is required. So what would a knowledge of the future then mean? It is possible to write about hopes, expectations and dreams from the past to the future. The essential point often seems to be the idea of change. Actually, photo four is more expressive than photo three. So next it is worth focusing on the eloquence of the fourth shot.

During the period it is recaptured the tower of hospitality means the Round Tower. It also means a return to Vyborg. A suitable guide for acquainting ourselves with the spirit of the age is the Muonituslotan käsikirja (Lotta Svärd Catering Handbook), written by Elli Malmgren. In the chapter "Division of Labour in the Group", the duties of waitresses were described as follows: "[Waitresses] prepare sandwiches for the men, take care of food distribution, wash dishes, keep the workplace clean and tidy both during and after work, pack and organize the stores according to lists, wash towels and facecloths, and assist the cook in the initial preparation of foodstuffs"(Malmgren, 1939, pp. 36-37).

The guiding principle of the era could have been hospitality as a duty. It probably means, at least in part, the same as hospitality as a profession. Without one or other of these elements, professional cultural activity is likely to remain soulless, devoid of spirit. In the tower of hospitality, such a procedure would not have worked. The era required dedication. The ability to assign yourself to a minor role was also needed. The ideal of selfless hospitality prevailed. Only honesty of action and dedication could guarantee that war-induced fear would be overcome. It also had to be in harmony with the historical dignity of the place.

The letter to the future could begin as follows: "Dear generations of the ages to come, will you ever be able to truly understand what we have been and are going through right now. It may well be that only those who have actually experienced it for themselves grasp the meaning of the events. Stories heard or read can only convey some kind of approximation of the world of my time." Thus, imagination and empathy will probably remain the means of understanding for the person of the future. And on 
their basis interpretations will then be made. Perhaps it simultaneously becomes fiction: truth and fable mingle and merge into each other. What if that really is the ultimate purpose of time travel?

The opposite direction, from the future to the past, would also be of interest with regard to sending a time letter. As a recipient the human of a bygone age would probably find it particularly difficult to imagine the path to the present at the moment of posting. On the other hand, the person of the future might have difficulty to avoid adopting the role of an omniscient narrator. It would be so easy to hand out advice not to do such and such. The descendants' representative would presumably try to steer his predecessor away from making mistakes. Would he not then be playing an omnipotent God?

How to start a letter from the future to the past? Perhaps something like this would be appropriate: "Dear bygone person, I am a little unsure about the correct form of address, whether I should use informal or formal 'you'2. Using the polite 'you' form might have been a better mode of address than the familiar one. I'm a child of my time and I choose for myself the more familiar 'you' form. I would prefer not to seem intrusive. I know what all the things are that are waiting for you ahead. I'll venture to say that our nation is working honourably. Such hard and busy times will require a lot of effort. However, industry and diligence will be rewarded. Don't doubt it for a moment. Like many others, I am proud of you." Did I convey the spirit of my own modern age to the human of the past?

The above question should be answered, at least in part, in the affirmative. Our way of thinking and worldview are influenced by, for example, teaching at school, people close to us, literary fiction, films and public opinion. They control the content and formatting of a letter to be sent to the past. This is probably an inescapable fact. Photographs and literature always seem to depict a past that is more beautiful and innocent than our own present-day, which is why we long to go back there. People are nostalgic: they have a yearning for a lost past. This is why the Tower of Hospitality in photograph four is so cogently eloquent. In it, the ideal of hospitality would seem to manifest itself at its best.

A thorough examination of the matter still requires a piece of verbal or literary evidence to support the photograph. Kersti Bergroth's use of language is beautiful and sophisticated. Perhaps the bliss of bygone days also appears in her phrasing. Kadonnut kaupunki (The Lost City), a work about Vyborg, touches even today's readers. Bergroth wrote it together with Lempi Jääskeläinen and Viljo Kojo. For example, this work may well have shaped the modern person's image of the era associated with the Tower of Hospitality. It is also apparent in the introductory sentences of the letter above written to the past.

Bergroth's description speaks to us appealingly: "Spring came to us Vyborgians along the seas and along the great lands of the east. It was some kind of world spring, bigger 
than elsewhere. Vyborg may have been small, but it received greetings from the ends of the earth, from huge distances. When I think of the Vyborg spring, I remember the tiny little details that radiate the dearest warmth, and the great big space-embracing feelings and moods. (Bergroth, 1951, p. 12.)

I now return to von Wright's thoughts, which were examined in the section "Contemporary Observations". After all, he stated that the word topos means place in Greek: the position of an object in relation to or compared to other objects. The Vyborg of the memory is a different place than the Vyborg of the imagination. To a modern person Bergroth's Vyborg means the Vyborg of the imagination. It would still seem justified to look at the past, present and future as time objects. When you look back from the present, you see things that have happened and that already exist. There again, when you look ahead, the horizon of time is perceived through the eyes of the soul, that is, as envisionments. The past often overflows with nostalgia. The future is filled with utopias. Yearning is involved in both directions. In other words, we dream of returning somewhere or arriving somewhere. The present moment is a dimensionless topos. The constant aim is to leave it, to move or travel somewhere.

Now we should move forward on our expedition. After all, the traveler thirsts to see the big wide world again.

\section{Amidst the ruins of time}

\section{Varkaus}

It is also possible to send a time letter to the Finland which has survived as Finland. Then the element of the lost local homeland disappears. Or Karelian evacuees had of course arrived in different parts of the country, including Varkaus and Turku. There was also talk of resettled Karelians or Karelian migrants. However, this is not a study of war migration. Therefore, we'll limit our discussion of an important topic to a short mention.

What would an inhabitant of bygone Varkaus write to a future inhabitant about his or her present? Or vice versa: what kind of letter would be sent from the Varkaus of the future to the Varkaus of the past? I'll begin my examination of the matter with a pair of pictures. 


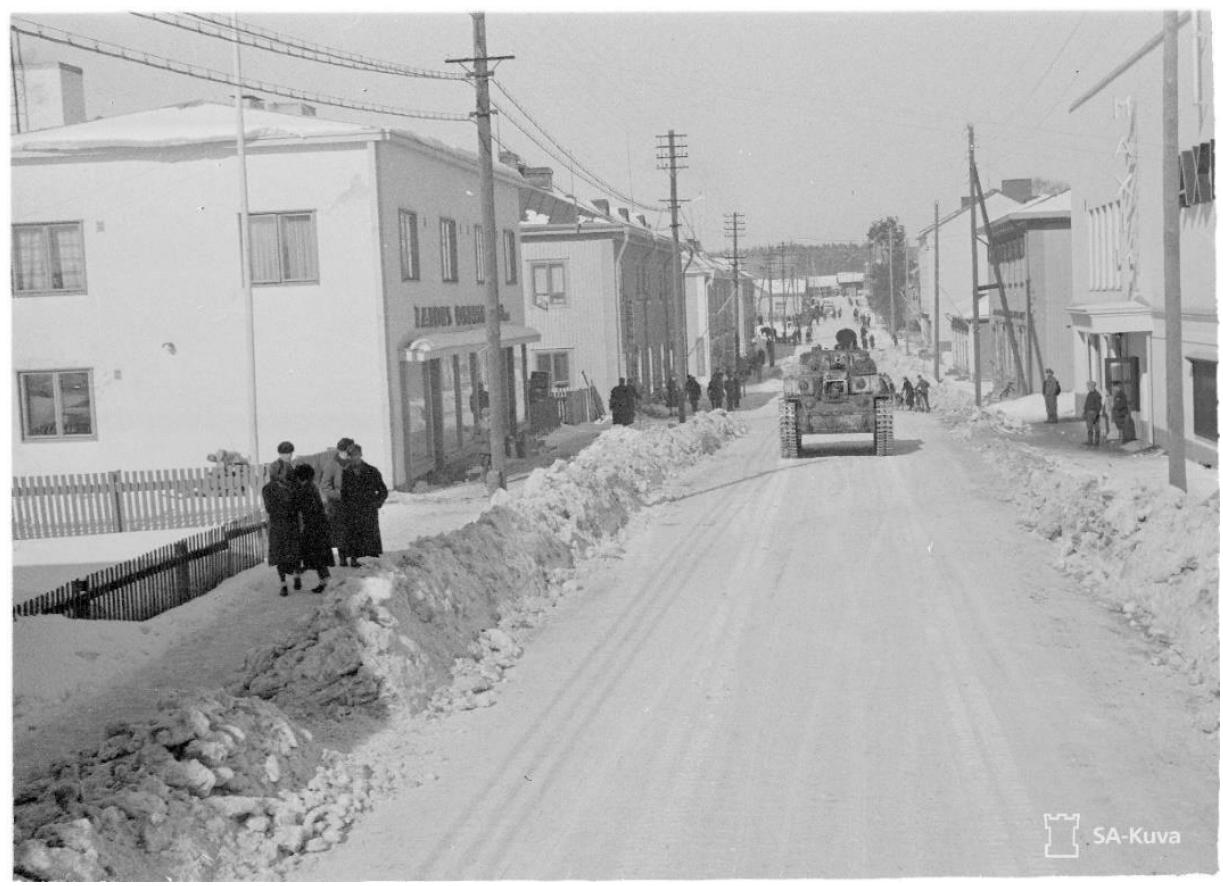

Photograph 5. Commercial Varkaus.

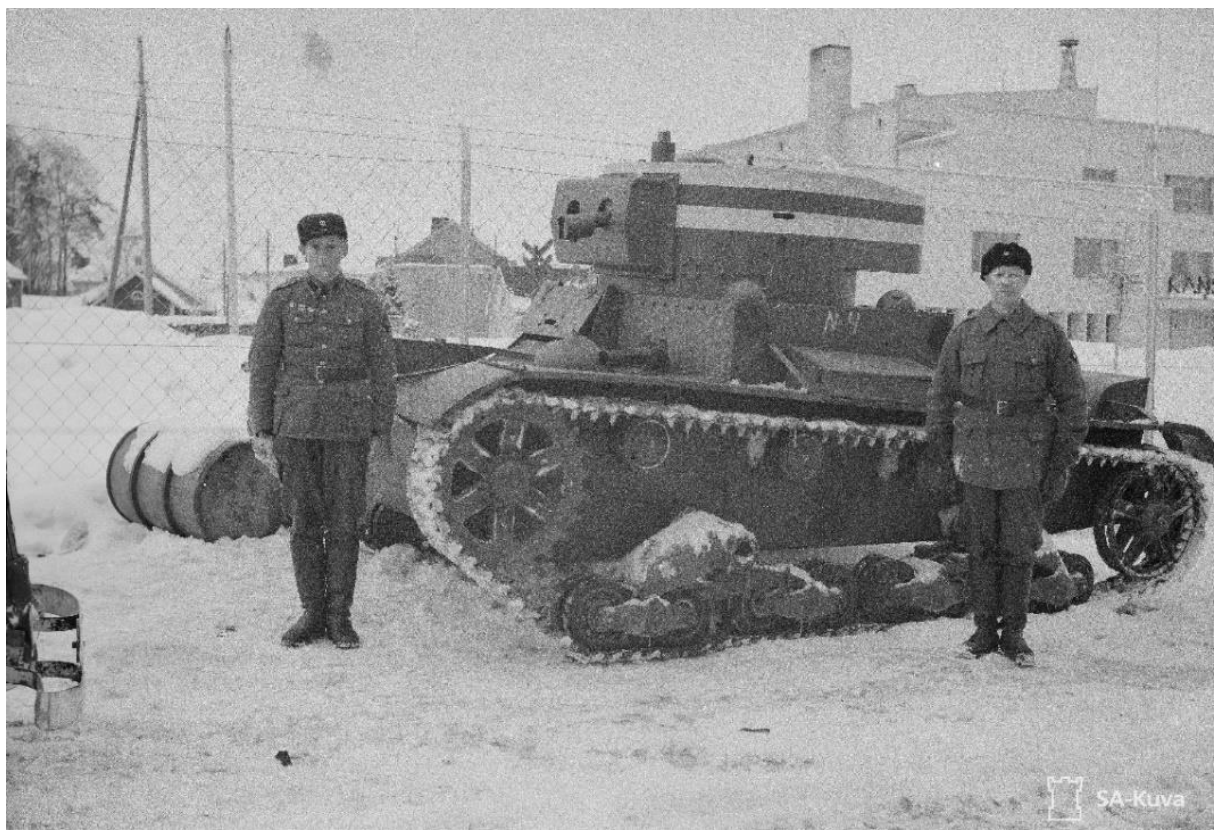

Photograph 6. Industrial Varkaus. 
In photograph six, a tank is driving along Mikkelintie towards Pirtinniemi. The functionalist Maxim cinema differs a lot from the other buildings on the street. Or, actually, there are at least three ages or times simultaneously presented in the view. A contemporary probably doesn't see or think about it. Only the gaze of a future person is capable of discovering this feature. It is also a good starting point for writing a time letter.

The dialogue with Dr Mazzarella is also still needed. Her thought-provoking work Täti ja krokotiili (The Aunt and the Crocodile) contains some high-quality essay writing. Mazzarella's text highlights the essentials: "Isn't it obsession with experiences combined with the contempt felt for tourists which is the reason we are fascinated by trips that still have the character of an individual adventure, trips that seem to have retained their authenticity? And if nothing else, we surely all nevertheless want our own life journey to be genuine - we don't want to be tourists in life." (Mazzarella, 1995, p. 229.)

The concept of war tourism is only possible from the perspective of the present. In other words, the idea of a time letter written from the present to the past is suitable for its analysis. The goal of modern man would presumably be to have intense experiences. It would probably be the experience of war he would write about in his communication. For him, a visit would be an adventure: a trip to the real sites of war. The requirement of authenticity would thus be fulfilled. He would defintely talk about war tourism and would call himself specifically a war tourist. So in no way whatsoever would he be a war tourist. Supposedly authenticity for him would be to get to ride along Mikkelintie in a tank. This would mean a partial restaging of the situation in photograph five. It would be about some kind of restoration of the past.

The tank and the functionalist cinema tell a story of different times. People of the future have only seen wartime in photographs and films. For them, then, it is somewhat imaginary. Standing face-to-face with a tank gun in a real war situation is different from looking at a photo. After all, there are real ammunition shells and in cinematography just likenesses of shells. Because of this, the man of the past probably does not understand the whole idea of war travel or war tourism. And there shouldn't be anything surprising about that. In such a situation, is consensus possible at all?

Photo five captures a wartime winter moment. It is one instant in the continuum of life. What kind of time letter could be sent from that existential trice to the future? It could begin with the following words: "It is late winter in the early 1940s. There is quite a severe frost. The existential stage is Varkaus' main street, Mikkelintie. This is the centre of business life. Or maybe busyness life, ceaseless, forward-moving existence 3 . From 'somewhere over there' the boom of war can be heard. Here, everyday life continues. The Maxim cinema is showing news films from the front. There in the future, they are just short film reports. For us, they mean a lived life. This is not about an adventure. The fear is genuine. For me and my contemporaries, this is 
a bitter experience. My dear successors, maybe for you this is just an art experience. There is an unbridgeable gap between our views. Still, I wish you a safe future."

An extract from the possible reply from the human of the future: "I have looked with fascination at the overall entity formed by photos five and six. After all, they show a journey that starts from Taulumäki Square and ends in a workshop yard. This route could be shown at the present-day Maxim. I would love to watch a cinematographic trip back into history. It would be best if people were offered the opportunity to make an authentic journey in a real tank. That would be an unparalleled tourist experience with the right amount of speed and excitement. I could film it on my smartphone and post my video on the internet. Then other people would be able to admire my journey as well. That would be my war experience."

Indeed, the ideal of shared understanding would not be realized. The journey of both the past and the future human is certainly genuine. Nor do I believe that either thinks of themself as a tourist on their life journey. I don't even know if someone can be a tourist in their own existential narrative. Even the people in photos five and six were just living their lives. They had not been able to choose the era of their existence. They had arrived in a finished world, an existential framework that was there earlier than they themselves. The boundaries of their life story had thus been drawn even before they appeared. If someone transcends the boundaries of their life story, is he then inauthentic, fake? (See also Itkonen, 1993.)

The environment in photo six is Pirtinniemi: the heart of Varkaus' shipbuilding and munitions refurbishment. Here we are at the centre of Varkaus' metalworking industry. The tank in the photograph has also been refurbished in the Pirtinniemi workshop. In the background, behind the fence, stands the functionalist building of the Kansallis-Osake bank. War and the world of money were thus located side by side. Men dressed in military uniform seem proud of their status and mission. They must have been testing the tank's condition and operational readiness. If a person of the 2020s received a letter from the early 1940s, they would not be able to fully comprehend the prevailing spirit of the age in photos five and six. Nor would someone living through days of war fully understand the essence of this current present. When reading a letter from the distant future, they would surely be amazed and disturbed by descriptions of the information technology era and the coronavirus situation. Human beings are permanently tied to their own present moment. They need imagination to perceive and give shape to other eras. (See also Itkonen, 2012; 2015; 2018; 2020b, for reflections on Varkaus and the spirit of time and place.)

The investigation of Varkaus and Turku will continue in another context. Let this examination be the prelude to a major essay.

\section{Turku}


It is possible to be in the figurative, physical and mental ruins of time. Perhaps that first, the metaphorical aspect, is now the most pertinent. War destroys, and peace builds. Does such a rhythm of being also prevail in the rest of life? Or is it just a feature of times of upheaval?

The expressive power of photographs is needed once again.

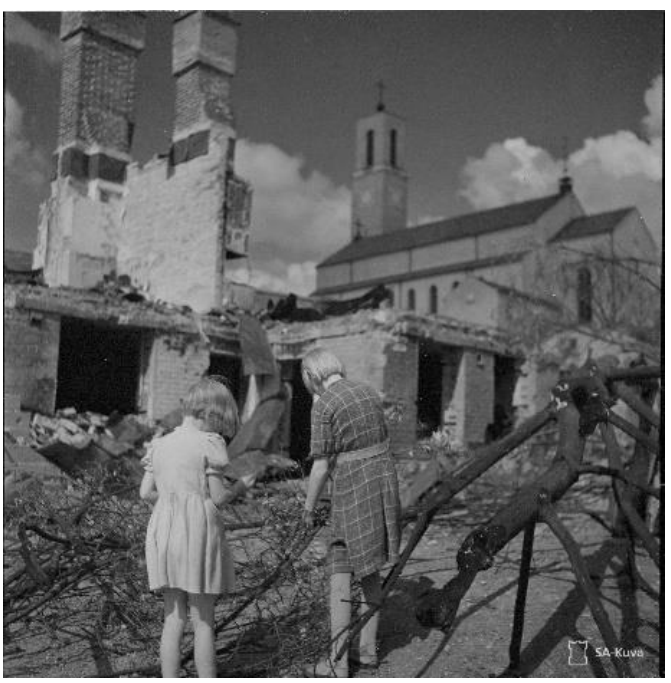

Photograph 7. Sotalaisten Hill.

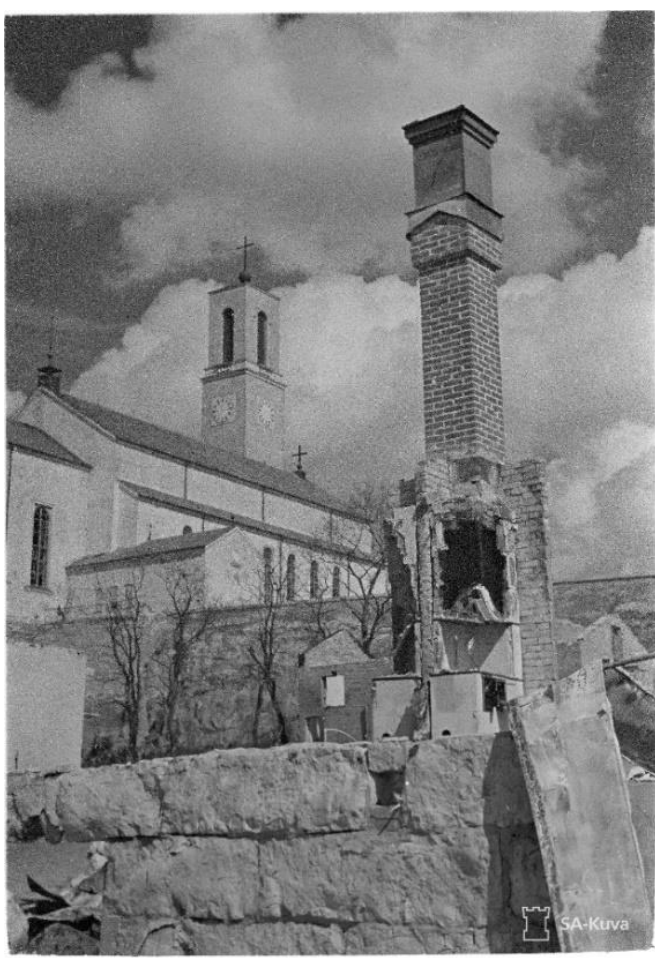

Photograph 8. Martin's Church.

There are many ways a person can be out there in the wide world. Therefore, a crucial element is also the quintessential nature of writing. Professor Mazzarella has interestingly characterized the nature of her essay writing in her book Elämä sanoiksi (Life into Words). With great merit she describes the telling of her own life story through writing: "I think of my essays in particular as an invitation to readers to reflect on their own answers. After all, an essay means an attempt, by nature an essay is not an absolute certainty but an open, curious sniffing around: Montaigne, the father of the essay, said that 'he was taking his mind for a walk'. I mostly write rather short sections, leaving a blank space between them. I don't want to connect these fragments together too tightly, I'd rather let readers draw their own conclusions about how they fit together. An empty space is an invitation for the reader to step inside and continue making associations. In recent years, I have also been greatly 
inspired by the blog format and the opportunities it provides for combining the big and the small, the experienced and the thought." (Mazzarella, 2013, pp. 41-42.)

It may well be that the essay and the photograph are similar in nature. In keeping with Mazzarella's interesting view, it is possible to think that each is an invitation to reflect on our own answers. Then the respondent also acts as the interrogator. The process is only successful using a thought-provoking photograph or text. It is then a soliloquy: a dialogic monologue inspired by a touching object of experience.

In photograph seven, two girls are standing amidst bombed-out ruins. In the background we see an out of focus Martin Church, as if on the horizon waiting for something. In photograph eight, on the other hand, the church is situated at the centre of perceptual reality. The hands are missing from the tower clock. Does the handsfree clock show the time is zero? Perhaps even when writing a travel letter, it would be worthwhile to follow Mazzarella's principle of leaving a blank space between short sections. The supposed reader fills the gaps by imagining their contents or imagining contents for them. The two pictures are really like an invitation for the reader to enter wartime Turku. The Martin Church seems to take on a symbolic meaning. The chimney rising from the ruins of time is also highly expressive. Now, however, instead of a travel letter, our investigations will focus on a present-day diary.

When a child keeps a diary, it contains no empty trivia. There are no lists with bullet points summarizing the day's events. In the same way, a letter is (hopefully) put together from encounters and experiences.

Nowadays, the problem is the consuming of experiences, some kind of ingestion of lived life. Email and the computer have more generally distanced people from the very essence of writing: you cannot write without being part of that same something. The idea of the technicalization and (at least partial) control of one's existence should probably be regarded as a kind of techno-utopia - and also as the existential milieu of machine man, robo sapiens. So let's move on from the consuming of experiences to the actual living of experiences.

What exactly would a modern-day diary look like? What would the modern person write in it? To whom or for whom would they make those written entries? Who would they invite in their text to be a reader of their diary? How would this be affected by the combining of opposites mentioned by Mazzarella? Would connecting the big and the small or the experienced and the thought to each other help make the writing interesting? Or even to formulate it to be warmly inviting? Mazzarella mentions the blog as a text format. So could today's diary be realized as an electronic document, i.e. as a web diary?

I have no hesitation in answering the above question in the negative. A modern-day diary must be in the form of a physical notebook, in which the entries are made by hand. Its essential elements, then, are pen and paper. In this context, I will focus on 
the modern diary of the 2020s. I will also engage in a discussion with photos seven and eight. Is it possible for me to act as an unreliable narrator? If so, whom would I be trying to mislead and why? In both photos, the towers rising up from the ruins of time seem to be stretching upwards to the sky. Are they reaching out towards a time of peace? Living in the modern age, I probably look at this scene of devastation in Turku in a different way than those living before me. Still, I would make my entry specifically for them, for those people, to read.

Neither photograph tells everything, meaning that both photos contain blank spaces. Continuing Mazzarella's line of thought, I could argue that blanks and gaps have been deliberately inserted in both images. For the viewer the empty space is an invitation to enter the photograph's time and world. Are the girls looking for firewood to heat their home? Did photo eight want to emphasize the important role of the church and religion in everyday life at a time of upheaval? Is that why the crosses stand out so distinctly against the sky? Even in the midst of destruction, there is still hope left. The spirit of Turku will not disappear. It will not cease to be the oldest and most poetic city in Finland. The people of Turku are even more proud of their bombed hometown. Would such things have been considered by my predecessors? Was the photographer thinking the same way when he composed the view? As a modern person, I can only get answers to my questions using my imagination. However, I venture to say that the photographs speak to me. Without them, I wouldn't be able to imagine anything. Wartime Turku would remain a mute era for me.

I can only indirectly become part of the world of previous generations. I can read various signs of the times in retrospect. They have invited me to reflect on the missing answers. I fill in the missing parts myself and mark them on my interpretative path. So it is that in these my modern-day journal entries I move along that trail. It is entirely possible that my predecessor would build a different path than I have. He might get lost as my path proceeds. Each of us sees the same path in our own way. There are, then, paths for the writer and the reader. They are not separate but nested pathways to being and time where it is good for the writer and the reader to go side by side. It means a stereophonic or dual-channel modern world, with the gaze directed from the present to the past and from there back to the present. It is an omniscient gaze. (See also Itkonen, 2019; 2020a, for reflections on Turku and the spirit of time and place.)

\section{Conclusion}

It is probably reasonable to assume that the future is usually imagined to be more developed and more technicized than each moment of the present. Imagination is almost always about a utopia, an ideal time and an ideal society. Humanity needs futuristic fantasies and visions. Otherwise, development will stop.

In her book Ei kaipuuta, ei surua (No Longing, No Sorrow), Professor Mazzarella dealt interestingly with the theme of the future dream. In it she describes one day in the life 
of Zacharias Topelius. Topelius imagines the twentieth century and new age Helsinki. These are his views of 20th-century Helsinki: "He had often thought of it: the century of mechanics had begun. It was only a matter of time before we would be able to turn water into fuel, when we would sail unobstructed in the sea of the air and beneath the ocean surface, when we would photograph the surface of the moon from a kilometer away, or find the one and only element of which all the existing sixty or seventy socalled simple elements are mere variations. [- - ] He had imagined a canal from Töölönlahti to the North Harbour, he had imagined huge factory buildings lining the bay, he had imagined electric-powered ships and electric trams criss-crossing the harbour." (Mazzarella, 2009, pp. 27-28.)

Topelius's utopia is reminiscent of the world depicted in films about the future. His vision is harmonious and full of hope. Technology serves people. It does not enslave anyone. In its electrified form, the future presents itself as a time of happiness and efficiency. It means the poet's view of the days lying ahead. Even modern people find such a view thought-provoking.

English translation by Glyn Hughes

\section{Notes}

1) The text is the first in a series of essays from which a Finnish national self-image will be constructed. My philosophical research will also examine the spirit of time and place. I shall draw a verbal artistic creation from the different ages of Finland.

2) Translator's note. Finnish has two forms for the word 'you'. The singular 'sinä' is informal, suggesting friendliness and casualness, whereas the plural form, 'te', when used to address just one person, is considered more formal and polite.

3) Translator's note. The Finnish word for 'business' is 'liike'. The same word also means 'movement, motion'.

\section{References}

[1] Bergroth, K. (1940). Nuoren lotan päiväkirja. [Diary of a Young Lotta Svärd]. Second impression. Helsinki: Otava.

[2] Bergroth, K. (1951). Kaupunki eri vuodenaikoina. [The city in different seasons]. K. Bergroth, L. Jääskeläinen and V. Kojo Rakas kaupunki. [Dear city]. Illustrations by E. Lehikoinen. Helsinki: Otava, 8-18.

[3] Itkonen, M. (1993). Kronos ja kairos. Paluu itseen - Martin Heidegger ja Eeva-Liisa Manner. [Kronos and kairos. Return into one's self - Martin Heidegger and Eeva-Liisa Manner]. Pohdin 8. Filosofinen aikakauskirja. Edited by J. Varto. Filosofisia tutkimuksia Tampereen yliopistosta (FITTY), volume 42. Tampere: Tampereen yliopisto, 86-107.

[4] Itkonen, M. (2012). Kulttuurimatkalla maailmassa. Filosofinen tutkielma ajasta, olemisesta ja suomalaisuudesta. [On a cultural journey in the world. 
A philosophical examination of time, existence and being Finnish]. Mielin kielin kaupungissa. Esseitä ruoka- ja matkailukulttuurista. Edited by M. Itkonen and V. A. Heikkinen. Helsinki: Haaga-Helia ammattikorkeakoulu, 13-193.

[5] Itkonen, M. (2015). Minä, kameleonttikuluttaja. Tutkielma toden ja tarun rajamailta. [Me, the chameleon consumer. A study of the borderlands of truth and tale]. Kameleonttikuluttajan paluu. Aikamatkaaja kotiseutua, maailmankylää ja elämystä etsimässä. Edited by M. Itkonen, V. A. Heikkinen and S. Inkinen. Helsinki: Haaga-Helia ammattikorkeakoulu, 15-106.

[6] Itkonen, M. (2018). Sormunen, Itkonen ja murroskohtien Suomi. Kokeellisia tutkielmia henkisen kulttuurin tilasta. [Sormunen, Itkonen and the Finland of upheavals]. Kokeellinen kameleonttikuluttaja. Kokemuksellisia tutkimusmatkoja satavuotiaaseen Suomeen. Edited by M. Itkonen, V. A. Heikkinen and S. Inkinen. Haaga-Helian julkaisuja 5/2018. Helsinki: HaagaHelia ammattikorkeakoulu, 11-82.

[7] Itkonen, M. (2019). Eurooppa, Suomi ja ajan henki. Kulttuurimatkalla V. A. Koskenniemen kanssa. [Europe, Finland and the spirit of the age]. Maailman Turussa. Pohdinnallis-esseistisiä kulttuurikävelyjä Aurajoen rannoilla. Edited by M. Itkonen, V. A. Heikkinen and S. Inkinen. Haaga-Helian julkaisuja 5/2019. Helsinki: Haaga-Helia ammattikorkeakoulu, 19-76.

[8] Itkonen, M. (2020a). The Many Faces of Turku - An Essayistic Study of Urban Travel. English translation by G. Hughes. European Journal of Language and Literature Studies. Volume 6, Issue 2, 89-99.

[9] Itkonen, M. (2020b). Valiant, vital and virtuous - A time-snap review. English translation by G. Hughes. European Journal of Multidisciplinary Studies. Volume 5, Issue 1, 17-25.

[10] Jääskeläinen, L. (1940). Kaunis, vanha Viipuri. [Beautiful old Viipuri]. Karjala - muistojen maa. Karjalan Liiton muistojulkaisu. Edited by O. Paavolainen. Porvoo: WSOY. (Page numbers missing.)

[11] Malmgren, E. (1928/1938). Muonituslotan käsikirja. [The Lotta Svärd's Handbook]. Fifth impression. Lotta-Svärd julkaisu n:o 10. Helsinki: LottaSvärd.

[12] Mazzarella, M. (1995). Täti ja krokotiili. [The Aunt and the Crocodile]. 4th impression. Finnish translation by K. Ripatti. Helsinki: Kirjayhtymä.

[13] Mazzarella, M. (2004). Marraskuu. Kertomuksia. [November. Stories]. Finnish translation by R. Viitanen. Helsinki: Tammi.

[14] Mazzarella, M. (2009). Ei kaipuuta, ei surua. Päivä Zacharias Topeliuksen elämässä. [No longing, no sorrow. A day in the life of Zacharias Topelius]. Finnish translation by R. Rintamäki. Helsinki: Tammi.

[15] Mazzarella, M. (2013). Elämä sanoiksi. [A life into words]. Finnish translation by R. Rintamäki. Helsinki: Tammi. 
[16] Mazzarella, M. (2018). Alma. Edelläkävijän tarina. [Alma. The tale of a pioneer]. Finnish translation by R. Rintamäki. Helsinki: Tammi.

[17] von Wright, G. H. (1995/1996). Ihminen kulttuurin murroksessa. [Man in the transformation of culture]. Finnish translation by J. T. Aro, R. Hannula and H. Nyman. Helsinki: Otava.

\section{Picture sources}

SA picture archive. From the front line to the home front 1939-1945.

[1] Photograph 1. Photographer military official A. Lindeberg. Online at http://sakuva.fi/.

[2] Photograph 2. Photographer corporal E. Heinänen. Online at http://sakuva.fi/.

[3] Photograph 3. Photographer K. Anttila. Online at http://sa-kuva.fi/.

[4] Photograph 4. Photographer military official T. Nousiainen. Online at http://sa-kuva.fi/.

[5] Photographs 5 and 6. Photographer unknown. Online at at http://sa-kuva.fi/.

[6] Photographs 7 and 8. Photographer E. Mäkinen. Online at http://sa-kuva.fi/. 